\title{
KETONIC AND ENOLIC MODIFICATIONS OF COMPOUNDS.
}

\author{
BY GERVAISE LE BAS.
}

(A Paper communicated by the Author to the TRANSACTIONS OF THE FARADAY Society. Reccived November 22, 1917.)

A very important subject is that connected with the change from the ketonic to the enolic structure and vice versa. The results which have been obtained are different in most cases from those found by other writers. The following examples have been taken from data given by Smiles, The Relations between Chemical Conslitutions and Some Physical Properties.

(I) Acetyl acetone, $\mathrm{CH}_{3} . \mathrm{CO} \cdot \mathrm{CH}_{2} . \mathrm{CO} \cdot \mathrm{CH}_{3} \cdot \quad \mathrm{M}_{a} 27^{\circ} 45$

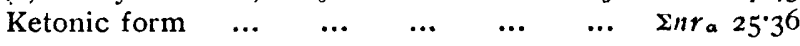

Enolic forms-

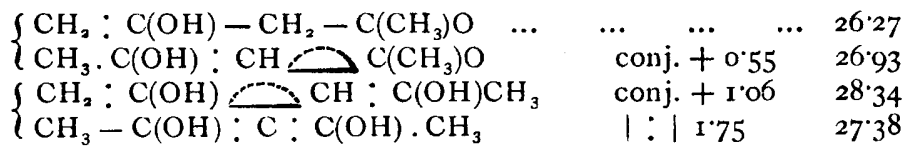

It is thus clear that acetyl acetone is the pure di-enolic form. The above result shows that the last di-enolic form is the correct one.

Smiles, $M_{a} 27 \% 45$. Di-enolic $27 \% 33$ calc.

Perkin (molecular magnetic rotations), Keto-enol 80 per cent.

$$
\text { Enolic } 20 \text {, }
$$

(2) Methyl acetyl acetone, $\mathrm{CH}_{3} \cdot \mathrm{CO} \cdot \mathrm{CH}\left(\mathrm{CH}_{3}\right) \cdot \mathrm{CO} \cdot \mathrm{CH}_{3} \cdot \quad \mathrm{M}_{\mathbf{a}} 30^{\circ} 75$

$\begin{array}{llllllllll}\text { Ketonic form } & \ldots & \ldots & \ldots & \ldots & \ldots & \ldots & \ldots & \operatorname{\Sigma nr}_{a} 29^{\circ} 96\end{array}$

Enolic forms-

$\mathrm{O}: \mathrm{C}\left(\mathrm{CH}_{3}\right)-\mathrm{CH}\left(\mathrm{CH}_{3}\right)-\mathrm{C}(\mathrm{OH}): \mathrm{CH}_{2} \quad \ldots \quad \ldots \quad 30.87$

$\mathrm{O}: \mathrm{C}\left(\mathrm{CH}_{3}\right) \div \mathrm{C}\left(\mathrm{CH}_{3}\right): \mathrm{C}(\mathrm{OH}) \cdot \mathrm{CH}_{3}$ conj. $+0.55 \quad 3 \mathrm{O}^{\cdot 53}$

$\begin{array}{lllllllll}\text { Di-enolic } \ldots & \ldots & \ldots & \ldots & \ldots & \ldots & \ldots & \ldots & 3 I^{\circ} 9^{8}\end{array}$

The first formula seems to be the correct one.

Smiles, Ma $30 \cdot 75 . \quad$ Mono-enol $30^{\circ} 89$

Di-enol $3 I^{\circ} 90$

Perkin (molecular magnetic rotations), Di-ketonic $46{ }^{\circ} 4$ per cent.

Keto-enol 53.6 , 
The advantage of the above method is that it shows which of the monoenols is the correct one.

(3) Ethyl oxalo-acetate, $\mathrm{C}_{2} \mathrm{H}_{5} . \mathrm{OOC} . \mathrm{CO} \cdot \mathrm{CH}_{2} \cdot \mathrm{COOC}_{2} \mathrm{H}_{5} \cdot \quad \mathrm{M}_{a} 4^{\prime} 3^{8} 8$

This is a class of compound which is very interesting, as its exact formula can be obtained by comparing it with a well-known substance.
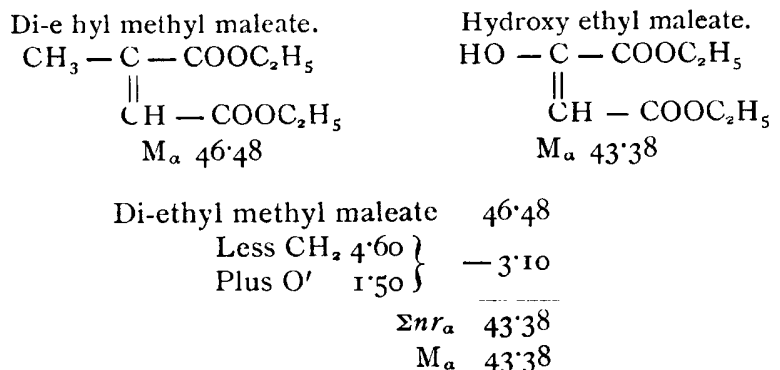

[There is thus no anomaly. See No. 6.]

The substance is again the pure one, and is hydroxy di-ethyl maleate.

$$
\text { Smiles } \quad \ldots \quad \ldots \quad \ldots \quad \ldots \quad \Sigma n r_{a} 43.46
$$

(4) Mesityl oxide oxalic ethyl ester-

$$
\left(\mathrm{CH}_{3}\right)_{2} \mathrm{C}: \mathrm{CH}-\mathrm{C}(\mathrm{OH}): \mathrm{CH}-\mathrm{CO} . \mathrm{CO}_{2} \mathrm{C}_{2} \mathrm{H}_{5} . \quad \begin{array}{r}
\mathrm{M}_{a} \\
56 \cdot 22 a \\
50^{\circ} \cdot 09 \beta
\end{array}
$$

Assuming that this compound is represented by the formula-

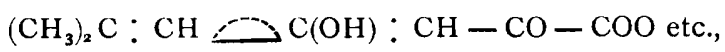

its refractivity would be

$$
\Sigma n r_{a} 5 \mathrm{r} \cdot 86
$$

Ketonic form-

$$
\left(\mathrm{CH}_{3}\right)_{2} \mathrm{C}: \mathrm{CH} \cong \mathrm{CO}-\mathrm{CH}_{2}-\mathrm{CO}-\mathrm{CO}_{2} \mathrm{C}_{2} \mathrm{H}_{5} . \quad \Sigma n r_{a} 50^{2} 29
$$

The $\beta$ form is therefore ketonic.

The $a$ form has an extraordinarily high value, which cannot be accounted for, even if the substance be considered to be tri-enolic $\Sigma n r_{a} 53^{\circ} \circ 9$.

Also the manifestation or suppression of anomalies of compounds in solution cannot be accounted for, but a consideration of this question meeds to be separate.

(5) Methyl cyano-aceto-acetate, $\mathrm{CH}_{3}, \mathrm{CO} \cdot \mathrm{CH}(\mathrm{CN}) \cdot \mathrm{CO}_{2} \mathrm{CH}_{3} \cdot \mathrm{M}_{a} 33^{\circ} 80$.

$$
\begin{aligned}
& \text { Ketonic form- } \Sigma n r_{\alpha} \text {. } \\
& \mathrm{O}: \mathrm{C}\left(\mathrm{CH}_{3}\right)-\mathrm{C}(\mathrm{CN})-\mathrm{C}\left(\mathrm{OCH}_{3}\right): \mathrm{O} \quad \ldots \quad \ldots \quad 3 \mathrm{I} \cdot 65 \\
& \text { Enolic- }
\end{aligned}
$$

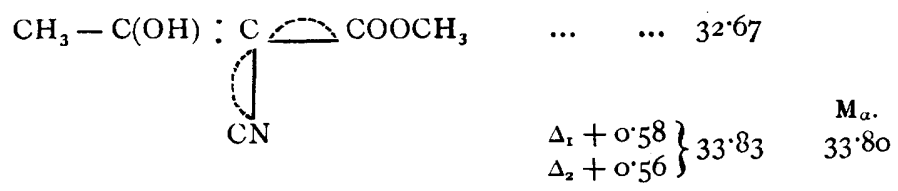


The anomaly for $\Delta_{2}$ for $-\mathrm{C}: \mathrm{C}, \mathrm{CN}$ is $+0^{\circ} 58$. The propionyl compound possesses a refractivity of-

$$
\mathrm{M}_{\mathrm{a}} 3^{8} \mathbf{4 0}^{\circ} \quad \operatorname{\nu in}_{\mathbf{a}} 3^{8 \cdot 32} \text { (calc.) }
$$

Smiles gives the following results : ketonic $35^{\circ} 97$, enolic $36^{\circ} 98$, and concludes that the substance is enolic.

(6) Acetyl malonic ester, $\mathrm{CH}_{3} \cdot \mathrm{CO} \cdot \mathrm{CH}\left(\mathrm{CO}_{2} \mathrm{C}_{2} \mathrm{H}_{5}\right)_{2} . \quad \mathrm{M}_{a} 48 \cdot 60$.

$$
\begin{aligned}
& \begin{array}{lllllllll}
\text { Ketonic form } & \ldots & \ldots & \ldots & \ldots & \ldots & \ldots & \ldots & 47^{\circ} \mathrm{O} 2
\end{array} \\
& \text { Enolic forms- } \\
& \begin{array}{llllll}
\mathrm{CH}_{2}: \mathrm{C}(\mathrm{OH})-\mathrm{CH}\left(\mathrm{CO}_{2} \mathrm{C}_{2} \mathrm{H}_{5}\right)_{2} & \ldots & \ldots & \ldots & \ldots & 47^{\circ} 79
\end{array} \\
& \begin{array}{lllll}
\mathrm{CH}_{3} \cdot \mathrm{C}(\mathrm{OH}): \mathrm{CO}_{2} \mathrm{C}_{2} \mathrm{H}_{5} & & & \\
\mathrm{CO}_{2} \mathrm{C}_{2} \mathrm{H}_{5} & \ldots & \ldots & \ldots & \Delta+\frac{0}{48 \cdot 04} \\
\hline 4^{8 \cdot 60}
\end{array}
\end{aligned}
$$

The expected anomaly is $+\mathrm{I}$ io for the conjugation of the two $\mathrm{CO}_{2}$ etc. groups. There are cases which theoretically involve a double anomaly such as the above, but which nevertheless show a single one.

The following cases illustrate this :-

Ethyl maleate-

$$
\text { Ma. } \quad \Sigma n r_{\mathrm{a}} . \quad \Delta .
$$

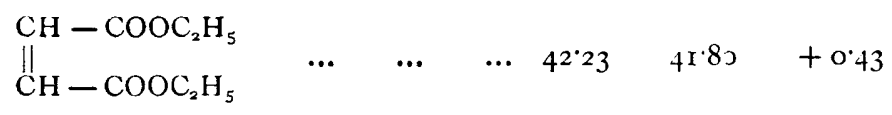

Methyl citra-conate-

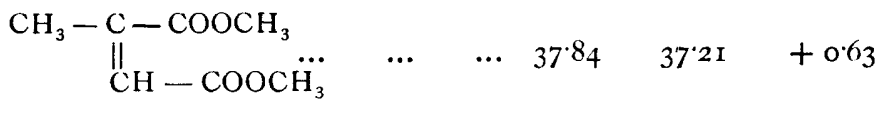

Ethyl citra-conate-

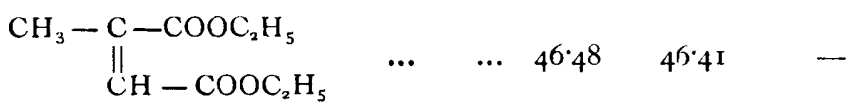

It is thus observed that the expected anomaly is reduced by half or disappears entirely. This is the most important point at present, since it shows that the diminution of the anomaly of acetyl malonic ester is not due to heterogeneity of substance, but to a similar cause to that which operates in methyl citra-conate, for instance. This leads us to conclude that acetyl malonic ester is homogeneous and possesses the formula already indicated.

(7) Ethyl acetone dicarboxylate $\mathrm{CO}_{2}$ etc.. $\mathrm{CH}_{2} \cdot \mathrm{CO} \cdot \mathrm{CH}_{2} \mathrm{CO}$ etc. $\mathrm{M}_{\alpha} 47^{\cdot 6}$ $\mathrm{CO}_{2}$ etc. $. \mathrm{CH}_{2} . \mathrm{C}(\mathrm{OH}): \mathrm{CN} \cong \mathrm{CO}_{2}$ etc. $\Sigma n r_{a} 47^{\circ} 75 \Delta 0^{\circ} 53$ Smiles $\Sigma n r_{a} 49^{\circ}{ }_{4}$ partially enotic.

\section{Aromatic Derivatives.}

In order to deal with the question, it will be necessary to calculate the anomaly shown by some simple benzene derivatives.

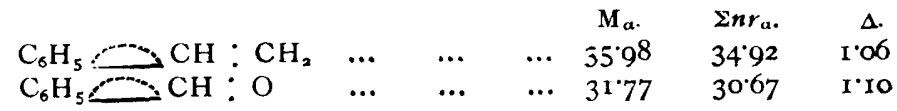


(I) Oxymethylene phenyl acetic ether--

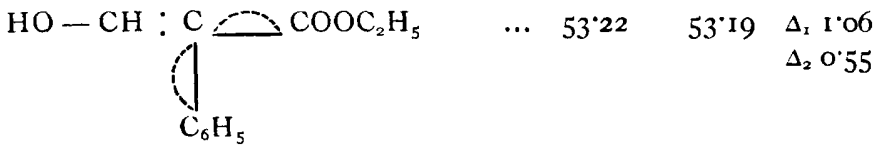

Formyl phenyl acetic ester (not known), possible formula for solid modification-

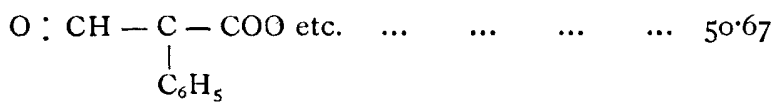

The calculated value of the first compound agrees with the observed value, a fact which confirms the formula attributed to it.

Smiles concludes that the form is enolic from-

Ketonic $5^{1} \cdot 07$
Enolic $5^{2} \cdot 08$

There is seen to be a considerable difference between $M_{\alpha}$ and $\Sigma n r_{\alpha}$.

(2) Acetate of $a$ oxymethylene phenyl acetic ester-

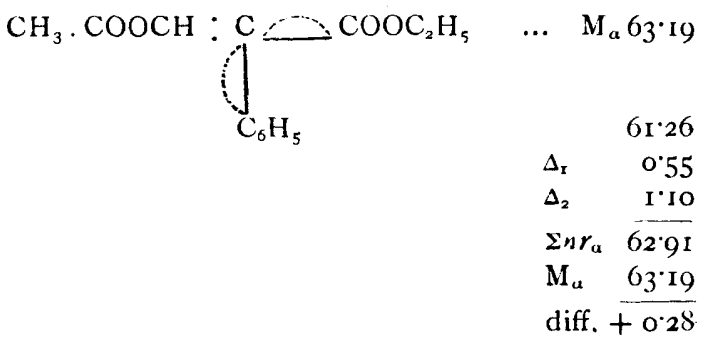

The number shows that the formula is as stated. Smiles gives the value $6 \mathrm{r} \cdot 50$ without the anomalies.

The most important conclusion is that in cases where one or more keto or enol forms are possible, only one form really exists, and that pure substances result-never mixtures. The different isomers appear to be mutually exclusive.

NoTE.-Acetone oxalic ester.

$\mathrm{CH}_{3} \cdot \mathrm{CO} \cdot \mathrm{CH}_{2} \cdot \mathrm{CO} \cdot \mathrm{CO}_{2}$ etc. $\mathrm{M}_{a} 39^{\circ} \mathrm{0} 8 \Sigma n r_{a} 39^{\circ} 20$. The substance is ketonic and not enolic as stated by Smiles. 